\title{
CLIMATE CHANGE INDUCED CHALLENGES ON DEFORESTATION: THE NEEDS TO EDUCE MITIGATION MEASURES IN NIGERIA
}

\author{
Yusuf Alapata AHMED * \\ Department of Geography and Environmental Management, University of Ilorin, Nigeria \\ e-mail: royalkayb@yahoo.com, yusufahmed579@gmail.com \\ Ismaila ALIYU \\ Department of Geography, Usmanu Danfodiyyo University Sokoto, Nigeria \\ e-mail: aleeyudas@gmail.com
}

\begin{abstract}
Citation: Ahmed Y.A., Aliyu I. (2019). Climate Change Induced Challenges on Deforestation: The Needs to Educe Mitigation Measures in Nigeria. Analele Universităţii din Oradea, Seria Geografie, 29(2), 64-76. https://doi.org/10.30892/auog.292107-807.
\end{abstract}

\begin{abstract}
Climate change induced challenges and ecologically degrading has been evident in persistent forest depletion in the world. This environmental problem has been in alarming rate most especially in the developing world. With global outcry on the consequences of constant unsustainable forest destruction topping the agenda of most contemporary intellectual discourses in the recent time. Thus, the need to examine the current deforestation situation necessitates a work of this nature. The analysis of challenges facing economic forest in Nigeria and the likely mitigation measures to embark upon in as to reduce the degradation of forest in the country is overdue. The paper establishes the existence of pressures on the forest communities in Nigeria due to number of causes such as; urbanization, overpopulation, mining and agricultural expansion programmers among others. For the nation to retain the forest resources that promote rural welfare, income and employment generation, urban and rural livelihood, poverty alleviation, and sustainable forest management, great attempt needs to be made to guide against human activities that encourage forest depletion. Potential forest degradation crises have made it clear that the environment and the economy can no longer be considered in isolation. At the same time, financial and economic crisis has provided the opportunity for policy interventions aimed at discouraging deforestation of the environment and renewed growth on more environmentally and socially sustainable.
\end{abstract}

Key words: deforestation, sustainable forest management, climate change

$$
* \quad * \quad * \quad * \quad * \quad *
$$

\section{INTRODUCTION}

Actions of mankind's on the environment and in his pursuit for development have resulted in a serious degradation of the ecosystem, thus pose a threat to the present and future generation. All human beings are attached to use the environment in three basic ways: as a resource bank - the 
environment supplies them with raw materials needed to maintain their existence, and their social and technological structures; as a habitat - people require more space per individual than any other species, and as sink for wastes- human beings produce more waste than other species (Ogundele and Oladipo, 2016). ${ }^{1}$ Deforestation has created one of the global development challenges, in particular, it is the most serious long term environmental problem facing the world and Nigeria is not an exception. Historically, the overzealous for all round development in Nigeria at the attainment of independence in 1960, was seen on rapid growth from a predominantly primary production based economy to an industrialized economy with strong inter-sectoral linkages. The optimism regarding the possibility of a significant progress towards attaining self-sustained and rapid industrialized development within a generation or two was heightened by the emergence of the unprecedented large foreign exchange earnings from crude oil. But after over four decades, this dream has remained largely unfulfilled in spite of all the development initiatives adopted. Adebayo (2010) opined that poor living conditions and illiteracy are causes as well as consequences of environmental degradation. The high level of poverty and illiteracy in Africa directly linked to the current level of environmental pollution and degradation in the continent. The poor and the illiterate are often more interested in issues related to their daily survival than environmental management; this lack of interest and awareness often lead to more reckless environmental behaviour which in turn breeds more environmental problems and leads to a vicious cycle of poverty. ${ }^{2}$

Nigeria lies between latitude and longitude of $10^{\circ}$ North and $8^{\circ}$ East. The location of major forests in Nigeria could be found in the Swamp forests, the Tropical Rainforests, and the Wooded Savannah in the southern axis of the country. The total land mass of Nigeria is about 910,770 $\mathrm{km}^{2}$ and among these, the total forest area covers about $110,890 \mathrm{~km}^{2}$ this representing about $12.18 \%$ of the total forest cover of the country. There are about 1417 known species of amphibians, birds, mammals and reptiles in the country (UNEP, 2004; Mfon et al., 2014). The forests are dominated by canopy trees with complex ecological system and the crowns of these trees intertwined as a result of their close-nit growth. Most of trees are perennial woody plants usually with stems which support branches and leaves. The height of some of these trees ranges from 8 meters to over 100 meters above sea level. Within the forests there are series of economic herbs, shrubs, climbers, lianas and other valuable plant species as well as mixed flora and fauna. Also, within the forest floor are litter and soil microbes which render forest soils fertile for tropical farming (Mfon et al., 2014).

Nigeria is naturally gifted with large extent of forest land with the swamp forests located in the extreme Southern part of the country with the tropical rainforest in the Southwestern fringe, while the wooded Savannah is glamorously found in the Middle-belt area of the country. Nigeria ranks among developing countries of the world with abundant forest resources, with about 60 percent of all known species of plant, 90 percent of all the world's non-human primates such as monkeys, and about 40 percent of all the birds of prey and about 80 percent of all the insects live in the tropical rainforests of the world (Park, 1992).

According to European Forestry Commission (2010), the world continues to lose some 15 million hectares of forests every year. Deforestation over the period 1980 to 1990 reached $8.3 \%$ of total forest area in Asia, 6.1\% in Latin America and 4.8\% in African. Most modern deforestation emerges in developing countries, particularly in tropical areas. Deforestation and forest degradation caused by climate change indirectly or directly threaten as many 400 million people including 50 million forest indigenous people who depend on forest for subsistence in sub-Sahara Africa (EFC, 2010). Deforestation estimates for some African countries as described by Lanly (1983) that the of forest depletion in Cote divoire and Nigeria is estimated as high as 5 to $6 \%$ per year while Ochanda and Epp (1982) stated that in Kenya the indigenous forest now covers only $1.9 \%$ and about $16 \%$ of the forest is being lost in each ten year period.

\footnotetext{
${ }^{1}$ http://en.wikipedia.org./wiki/deforestation

${ }^{2}$ http://en.wikipedia.org/wiki/Millennium
} 
Back home in Nigeria, the UNFAO ranked Nigeria in 2013 as having the highest rate of deforestation in the world (Aikhiombar, 2015). The regional breakdown of deforestation in Nigeria from 1979 to 1995 shows that total forest declined by $48 \%$ in the North-central $7 \%$ in the North East, $60 \%$ in the North West, $53 \%$ in the south East, $13 \%$ in the South-South and $12 \%$ in the South West (FORMECU, 1996). In 2000 the forest cover was estimated at 13.5 million hectares compared to 17.5 million hectares in 1990 (FAO, 2001), indicating a forest cover loss of close to 400 thousand ha per annum, or a decline of about $2.6 \%$. Forest/woodlands now stand at only $13 \%$ of the total land area (FAO, 2001). Hence, global observation on the challenges and consequences of continuous unsustainable forest destruction topping major intellectual agenda. This paper therefore focuses attention to global outcry on evil of deforestation status and tries to evaluate the urgent need for rigid mitigation measures to alleviate the impacts of climate induced challenges on deforestation in the tropical world including Nigeria.

\section{CONCEPTUAL ISSUES OF DEFORESTATION}

Deforestation refers to the felling, cutting and clearing of forest cover or vegetation includes tree plantations in order to pave way to agricultural, industrial, urban or rural land use. In other words, it involves termination of forest cover to make land available for residential, commercial and industrial purpose or both. Conversely, the removal of trees without sufficient replacement is always leading to reduction in habitat, wood, biodiversity, and quality of life in an ecological community. The term "Deforestation" is associated with modification of forestry layout such as; felling of wood for fuel, commercial logging and activities associated with temporary removal of forest cover such as slash and burn technique, all which is a major component of shifting cultivation agricultural systems. ${ }^{3}$ It is equally used to describe clearing of forest for grazing or temporary ranching. By and again, it is also involved the establishment of industrial plantations which may be considered as deforestation by some people while others may view it as afforestation. The consequences of deforestation are so massive and astonished, in that between 1990 and 2005, Nigeria has lost about 79\% of her old-growth forests (Rainforest Mangabay, 2007).

Over the last century the forest cover around the globe has been greatly compromised, leaving the green cover down to lower ebb of about 30 per cent. According to the United Nations Food and Agriculture Organization (FAO), an estimated 18 million acres (7.3 million hectares) of forest are lost each year around the world (Mfon et al., 2014).

Many countries in the developing world have been noted with the largest net loss of forests per year within 2000-2010, this was reduced to six million hectares per year as a result of reductions in Indonesia, Sudan, Brazil and Australia (see table 1). There were 28 countries and areas which have an estimated net loss of one per cent or more of their forest area per year. The five countries with the largest annual net loss for 2000-2010 were Comoros (-9.3 per cent), Togo (5.1 per cent), Nigeria (-3.7 per cent), Mauritania ( -2.7 per cent) and Uganda ( -2.6 per cent). The area of other wooded land globally decreased by about 3.1 million hectares per year during 19902000 and by about 1.9 million hectares per year during the last decade. The area of other wooded land also decreased during the past two decades in Africa, Asia and South America. Country Annual change 1990-2000 Country Annual change 1990-2000 1000 ha/year \% 1000 ha/year \% Brazil -2890 -0.51 Brazil -2642 -0.49 Indonesia -1914 -1.75 Australia -562 -0.37 Sudan -589 -0.80 Indonesia -498 -0.51 Myanmar -435 -1.17 Nigeria -410 -3.67 Nigeria -410 -2.68 Tanzania -403 1.13 Tanzania $-403-1.02$ Zimbabwe $-327-1.88$ Mexico $-354-0.52$ the Congo $-311-0.20$ Zimbabwe -327 -1.58 Myanmar -310 -0.93 Congo -311 -0.20 Bolivia -290 -0.49 Argentina -293 0.88 Venezuela $-288-0.60$ Total $-7926-0.71$ Total $-6040-0.53$ (see table 2). Countries with largest annual net loss of forest area, 1990-2010 (Anonymous, 2010).

\footnotetext{
${ }^{3}$ http://en.wikipedia.org./wiki/deforestation
} 
Table 1. Annual change in forest area in Africa, Asia and Europe region and sub-region, 1990-2010 Source: Anonymous, 2010, as modified by the Authors

\begin{tabular}{|c|c|c|c|c|}
\hline \multirow{2}{*}{ Region/sub-region } & \multicolumn{2}{|c|}{$\mathbf{1 9 9 0 - 2 0 0 0}$} & \multicolumn{2}{|c|}{$\mathbf{2 0 0 0 - 2 0 1 0}$} \\
\cline { 2 - 5 } & $\mathbf{1 0 0 0}$ ha/year & \% & $\mathbf{1 0 0 0}$ ha/year & -0.66 \\
\hline Eastern and Southern Africa & -1841 & -0.62 & -1839 & -0.05 \\
\hline Northern Africa & -590 & -0.72 & -41 & -0.46 \\
\hline Western and Central Africa & -1637 & -0.46 & -1535 & 0.49 \\
\hline Total Africa & -4067 & -0.56 & -3414 & 1.16 \\
\hline East Asia & 1762 & 0.81 & 2781 & -0.23 \\
\hline South and Southeast Asia & -2428 & -0.77 & -677 & 0.31 \\
\hline Western and Central Asia & 72 & 0.17 & 131 & 0.39 \\
\hline Total Asia & -595 & -0.10 & 2235 & n.s. \\
\hline Russian Federation (RF) & 32 & n.s & -18 & 0.36 \\
\hline Europe excluding RF & 845 & 0.46 & 694 & 0.07 \\
\hline Total Europe & 877 & 0.09 & 676 & \\
\hline
\end{tabular}

\section{THEORETICAL ISSUES OF DEFORESTATION}

Deforestation is one of the important issues in our global climate change age-long discussions. Forest resources can provide long-term national economic benefits. For example, at least 145 countries of the world are currently involved in wood production (Anonymous, 1994). However, sufficient evidence is available that the whole world is facing an environmental crisis on account of heavy deforestation (Andronache et al., 2019; Foley et al., 2005; Pintilii et al., 2017; Sumit et al., 2012). The issues lead to two important environmental challenges such as; loss of biodiversity and increasing of greenhouse gas emission. Many efforts have been introduced, developed and implemented. However, a declining forest cover still persists. Since deforestation is a complex and intertwined issue, understanding its complexity and context on which it is debated is fundamental. There are three major schools of thought associated with the causes of deforestation. The first is the Impoverishment School of Thought (IST) which is of the opinion that, the major cause of deforestation is the increase in the number of poor people; that is, small holders are the principal agents of deforestation. The second school thought is the Neoclassical Group School (NGS) which believes that, deforestation is caused by open access property rights. That is, there are various agents with respect to deforestation. The third school is the PoliticalEcology Group (PEG) which believes that, deforestation is caused by capitalist entrepreneurs. ${ }^{4}$

Deforestation could have influence on climate within local or at global degrees through changes in the energy, mass and momentum fluxes between climate subsystems energy reservoirs. Deforestation is also associated with $\mathrm{CO}_{2}$ emissions, as crops and marginal lands that usually replace trees after land clearing tend to hold less carbon per unit area than forests (Bala et al., 2007). The radiative forcing associated with an increase in atmospheric $\mathrm{CO}_{2}$ is, from a climatic perspective, the most important biogeochemical impact of deforestation. Increases in $\mathrm{CO}_{2}$ also have the potential to affect climate by altering transpiration rates, due to $\mathrm{CO}_{2}$ increased water use efficiency reducing stomatal conductance and increasing plant growth (Friedlingstein et al., 1999; Larcher, 2001). The biogeophysical impacts of deforestation most pertinent to climate infusion are changes to surface albedo, evapotranspiration (ET) and surface roughness length (Bounoua et al., 2002). Croplands and pastures tend to have higher albedo than forests, which causes them to absorb a smaller fraction of the incoming solar radiation. Trees tend to have deeper rooting depth than crops and grasses such that tree removal implies a decreased ET and associated reduction in latent heat flux (Bala et al., 2007; Kliedon, 2000). ET can also be reduced through the reduction in canopy capture following deforestation, as well as from reduced turbulence associated with a lower aerodynamic roughness length and colder temperatures. For large-scale land cover change the alterations in ET could influence cloud formation potentially impacting atmospheric albedo and atmospheric long wave absorption (Bala et al., 2007).

\footnotetext{
${ }^{4}$ http://en.wikipedia.org/wiki/deforestation.
} 


\section{DEFORESTATION AND CLIMATE INDUCED CHALLENGES SYNOPSIS}

The removal of trees without sufficient aforestation could lead to reduction in ecological inhabitants, biodiversity as well as wood and quality of life; this could be referred to as deforestation. The use of the term "Deforestation" at times is connected with alteration of forestry issues. It is used to denote activities that use the forest, for instance, felling of wood for fuel, commercial logging and activities associated with temporary removal of forest cover such as slash and burn technique, which is a major component of shifting cultivation agricultural systems or clear cutting. It is equally used to describe clearing of forest for grazing or ranching. Also, an activity such as the establishment of industrial plantations may be considered as deforestation by some people while others will view it as afforestation. The consequences of deforestation are so massive, that between 1990 and 2005, Nigeria has lost a staggering 79\% of its old-growth forests (Rainforests Mangabay, 2007).

Over the last century the forest cover around the globe has been greatly compromise, leaving the green cover down to lower ebb of about 30 per cent. According to the United Nations Food and Agriculture Organization (FAO), an estimated 18 million acres (7.3 million hectares) of forest are lost each year (Mfon et al., 2014).

\section{CLIMATE INDUCED CHALLENGES ON FORESTS}

Forests are vital to our Earth. About 60 million humans are indigenous who are completely dependent on native woods. Trees purify our air, filter our water, prevent erosion, and act as a buffer against climate change. Trees also offer a home to plant and animal species, while they providing natural resources such as medicine, food, timber, and fuel to about 300 million people who live in forests worldwide. But where trees provision is contrary, climate acts and induces various challenges (Habitat, 2017).

Not long ago, scientists have reached a consensus on the existence of climate change, even though the exact scope of this phenomenon remains somewhat uncertain. In 2007, the International Panel on Climate Change (IPCC) concluded in its Fourth Assessment Report (FAR) that warming of the climate system is unequivocal. During the twentieth century, the average global temperature increased by $0.76{ }^{\circ} \mathrm{C}$, and it is expected to increase further by $1.8^{\circ} \mathrm{C}$ to $4^{\circ} \mathrm{C}$ during the twenty-first century. Consequently, sea levels rose by 17 centimeters during the last century, rising at a rate of 3.1 millimeters per year between 1993 and 2003. The extent to which sea levels are going to rise during the twenty-first century remains uncertain (Magrin et al., 2007). Though not taking into account ice sheet reaction, the IPCC forecast a further rise, between 18 and 59 centimeters, by the end of the century. In the recent time, the "Copenhagen Diagnosis" concluded that the "global sea level is likely to rise at least twice as much as projected." Beyond global warming and sea level rise, climate change is highly likely to result in more frequent and more severe weather phenomena, such as droughts, heavy rainfall, intense heat, and tropical storms (McCarthy et al., 2007). Undoubtedly, the climate change is as a result of human activity, in particular the emission of greenhouse gases (Walker and Sydneysmith, 2007). Although human beings are responsible for climate change, they also suffer from its diverse consequences. Economic activities, such as agriculture, forestry, and fishery, may be locally impeded (Betts, 2000). Human life and health are also affected due to extreme heat, natural disasters, and a resurgence of certain diseases such as malaria, which together are estimated to cause over 140,000 excess deaths annually world over. One of the most dramatic human consequences resulting from climate induced challenges due to global warming have unique impacts on human settlements. Climate change is degrading the conditions of life in many inhabited territories, sometimes forcing people to move.

Deforestation can impact climate on local and global scales by changes in the energy, mass and momentum fluxes between climate subsystems energy reservoirs. ${ }^{5}$ Deforestation is also associated with $\mathrm{CO}_{2}$ emissions, as crops and marginal lands that usually replace trees after land

\footnotetext{
${ }^{5}$ http://en.wikipedia.org/wiki/Millennium
} 
clearing tend to hold less carbon per unit area than forests (Betts, 2000; Bala et al., 2007). The radiative forcing associated with an increase in atmospheric $\mathrm{CO}_{2}$ is, from a climatic perspective, the most important biogeochemical impact of deforestation. Increases in $\mathrm{CO}_{2}$ also have the potential to affect climate by altering transpiration rates, due to $\mathrm{CO}_{2}$ increased water use efficiency reducing stomatal conductance and increasing plant growth (Larcher, 2001).

\section{CAUSES OF DEFORESTATION IN NIGERIA}

\section{Climatic induced challenges}

This cause can be divided into three major broad groups: Climatic agents, Biotic agents, and Man/Animals.

a) The climate agents in common, represent the average weather conditions of the country over a long period of about 50 years. They include sunlight, water and wind. Sunlight is very essential during photosynthesis, but with high intensity of sunlight, it has negative impacts as it kills plants especially at the tender age. Water is equally necessary for the growth of plants. However, its excess for long periods in the northern and southern parts of the country most plants may not survive extremity or flooding. The wind on the other hand, is equally associated with deforestation but destructive wind may cause breaking of tree branches as well as uprooting of trees which remove vital vegetation from the ground and thus, resulting into open ground or drought.

b) The Biotic agents like microbes, animals and other plants. The microbes include; fungi, bacteria and viruses are in this category. These in all, attack all parts of plants thereby killing plants off and making ground to become barren. Other plants especially some tall trees provide shade which retards the growth of their own seedlings and seedlings of other plant species. Also, some other plants produce toxic chemical substances which are poisonous to other species (Nwoboshi, 1982).

c) Man/Animals as agents of deforestation have the greatest impact on forests as without their interference, the forest would have remained intact. The impacts of man/animals include; over logging, overgrazing, urbanization due to improper control of migration, attempting industrialization, illegal mining, felling of trees without replenish or replacement, over-extraction or fetch-wood for fuel and ill-control of charcoal making as well as, uncaptioned and improper opening of forests to public for tourism, all these cause more untenable and damage to many Parks and Sanctuaries in Nigeria. While the impacts of animals such as; insects, rodents, worms and large herbivores which feed on trees can equally be felt to have impacts on deforestation in the country (Ogundele and Oladipo, 2016).

\section{Expansion of Farming Land}

About $60 \%$ of the clearing of tropical most forests are meant for agricultural settlement (Myers, 1994). But for the fact that, more than $80 \%$ of the Nigeria populace are into farming. Therefore, more people are found in agricultural resettlement and thus, more people are induced on deforestation in the country. During agriculture the site is prepared through under brushing and felling leading to deforestation through slashing and burning activity in tropical forests which is utilized during shitting cultivation has led to the permanent destruction of the rainforest (Nwoboshi, 1982). Mostly all reports indicated shifting agriculture as responsible for about one half of tropical deforestation and some put it up to two thirds (Chakravarty et al., 2012).

\section{Urbanization and industrialization}

Increase in population has led to several houses and infrastructure springing up everywhere, thereby threatening the forests (NEST, 1992). For instance, Nigeria had a forest area of about 60 million hectares in 1897 , but after 100 years the country had only about 9.6 million hectares which represent a loss of 50 million hectares in 100 years (Carty, 1992). The sites for the University of Calabar as well as the sites of other first and second generation universities in Nigeria were highly forested areas. Similarly, the Army School of Artillery, the Nigerian Defence Academy and the 
Mobile Police Training School together used approximately 7420 hectares of forest reserves of Kaduna state while 18, 390 hectares of Ajaokuta forest reserve in old Kwara state was used by the steel plant (Carty, 1992). The federal capital territory claimed approximately 27, 330 hectares of forest reserves (Carty, 1992; Aderounmu et al., 1992). Also, the construction of road networks, railways, ports complex, airports have led to considerable deforestation, and invariably the loss of vast fauna population. Akintoye (2014) has also identified the consequences of the Nigeria Liquefied Natural Gas (NLNG) Project on biodiversity losses, although in a mangrove ecosystem in Bonny local government area of Rivers state in Nigeria. The present site of the NLNG, at old Finima, is believed to be the breeding area for some marine species like turtles. Also, Akintoye and Utang (2012) identified that where industries are created and there are negative consequences on the immediate local environment and invariably the host communities, there is no guarantee that significant benefits will accrue to the indigenous population.

\section{Logging}

Sawn timber is imperative in construction activities for residential, recreational and industrial development (see figures 1 and 2). In many cases in Nigeria, trees are felled and sawn without any commensurate effort to replant them, for instance, Ekinta forest reserve $\left(104 \mathrm{~km}^{2}\right)$ in Cross River State, south-south geo-political zone of Nigeria has been transformed from tropical high forests into grassland as a result of unsustainable agriculture and logging.

\section{Mining and Extraction}

As mining is very intensively lucrative, it is also very destructive and encourages deforestation (Mather, 1991; Sands, 2005). The mining area of land involved is quite small and it is not seen as a major cause of primary deforestation. Mining activity promotes development booms which may attract population growth but its consequence is deforestation. Moreover, Roads constructed to support the mining operations will open up the area to shifting agriculturists, permanent farmers, ranchers, land speculators and infrastructure developers. The construction of roads, railways, bridges and airports open up the land to development and bring increasing numbers of peoples to the forest frontier. If wood is used as fuel in mining operations and it is sources from plantations established for the purpose, it can cause serious deforestation in the region.

\section{Over Exploration and Exploitation}

The swamp forests of Southern Nigeria were previously protected from destruction or over exploitation due to their relative inaccessibility as a result of the swampy nature of the environment. However, today, these forests are being destroyed as a result of petroleum exploration, exploitation and spillage (Akachuku, 2007). Mining of several minerals in Nigeria such as bayrite, tin, coal etc has led to the destruction of the forests and scarification of the landscape.

\section{Over Grazing}

It is a well established fact that over grazing leads to a gradual change in vegetation from derived savannah to Sudan savannah as these animals feed on tree seedlings especially in the dry season when there is little grass to sustain them. These animals also feed on tree seedlings and branches of mature trees, thereby leading to deforestation (NEST, 1992).

\section{Corruption and political Interference}

The Food and Agricultural Organization (FAO) (2015) reports identified forest crime and corruption as one of the main causes of deforestation and warned that immediate attention has to be given to illegal activities and corruption in the world's forests in many countries (Chakravarty et al., 2014). Illegal forest practices may include the approval of illegal contracts with private enterprises by forestry officers, illegal sale of harvesting permits, under-declaring volumes cut in public forest, under pricing of wood in concessions, harvesting of protected free by commercial 
corporations, smuggling of forest products across borders and allowing illegal logging, processing forest raw materials without a license (Chakravarty et al., 2014). In Nigeria poaching, farmers and Fulani in the forests is corruptly allowed by forest guards.

\section{Fuel wood and Charcoal}

In Nigeria as in most third world countries, firewood and charcoal production constitute the major source of fuel. This scenario is aggravated by the rampant, unusual and high cost of kerosene leading to a lot of pressure on the forests. It becomes difficult to prevent people from cutting down the forest for firewood when there is no cheap and available alternative. This alternative source of fuel is often perceived to have devastating ecological and environmental effects. While little attention is being paid by the governments, forestry institutions, NGOs, to legislate policy measures to control felling of unauthorized trees using for charcoal making in some rural and urban areas in Nigeria.

\section{IMPACTS OF DEFORESTATION IN NIGERIA ENVIRONMENT}

Deforestation in Nigeria has tremendously impacted that are not only threatened, depleted or endangered biodiversity of the forest ecosystem but it has negative on ecological, genetic and socio-economic influence on the environment. The details of the impacts are as follow:

\section{Loss of biodiversity (Plants and Animals in the Environment)}

In the vegetation regions of Nigeria, many trees like; shrubs, herbs and several plant species have been over exploited especially those with edible seeds; nuts and kernels, are now endangered as well as some assorted animals have been reduced, while some are in danger of extinction. Also, most primates like; chimpanzees and gorillas, guenons, mangabeys, drills (marine animals), are now endangered (Akachuku, 2007).

In reality, the lowland gorilla which is endemic to the Cross River National Park at Mbe Mountain is seriously threatened through hounding and habitat destruction. Several large animals like; elephants and other mammals such as hippopotamus, manatees and leopards had decreased tremendously within the ecosystems, have disappeared, while reptiles such as crocodiles, monitor lizards, alligators, royal python and boa (constrictors) have diminished. Also, several species of amphibians, fruit bats, fishes, snails, birds e.t.c are threatened, endangered or extinct. Most stable crops have been "lost" whereof several younger generations of Nigerians may not know them. These "lost" plants are of serious economic importance (food, medicine,) to the country. They include algae, mushrooms, roots, vegetables, tubers, fruit trees, culinary plants, medicinal plants e.t.c (Okojie, 1993). For instance, Akintoye (2003), Akintoye et al (2013) and Mfon (2003) in studies carried out in Cross River state, have confirmed that losses of biodiversity, from logging and unsustainable NTFPs collection are serious threats to forests conservation in Nigeria.

\section{Atmospheric Pollution}

Deforestation is one of the major causes of enhanced green house effect. Trees and other plants remove carbon in form of carbon dioxide from the atmosphere during the process of photosynthesis. Carbon dioxide is injurious to animals including man and as deforestation takes place, the few trees left cannot make use of the carbon dioxide, therefore, the excess carbon dioxide gets into the atmosphere causing global warming. Deforestation is estimated to contribute up to one third of all carbon dioxide. The water cycle is equally affected by deforestation as trees extract groundwater through their roots and release it into the atmosphere. When deforestation takes place, the region may not hold as much water which can lead to a much drier climate. ${ }^{6}$

\footnotetext{
${ }^{6}$ http://en.wikipedia.org/wiki/deforestation.
} 


\section{Environmental Calamities (Acid rain, Desertification and Flood)}

With deforestation, most of the carbon dioxide produced by industries especially in the Niger delta cannot be absorbed by trees, therefore, acid rain is produced which damage roof tops and speeds up the weathering of buildings as well as chemically attacking plants and other living things. The Sahara Desert is encroaching into the southern parts of Nigeria and the encroachment is accelerated by deforestation. Also, there are incessant flood along the coastal areas of Nigeria and even in the north after torrential rainfall as the root of the trees which would have reduced the velocity of water runoff cannot serve the purpose because of deforestation.

\section{Depletion of Soil and Water Resources}

It has been established that most fishes and other aquatic animals breed under the root of some aquatic trees. With deforestation, some trees and animals' population become few, while large bare of land equally triggers the loss of several tones of soil from soil erosion leading to open bake land that reduced food production, creation of gully erosion and forced migration of people from the affected areas (see figure 3 ).

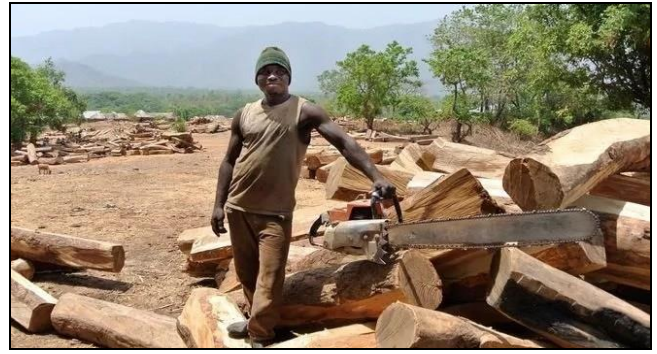

Figure 1. Logging in Nigeria environment Source: Adopted from, Naij.com, media Ltd.2019

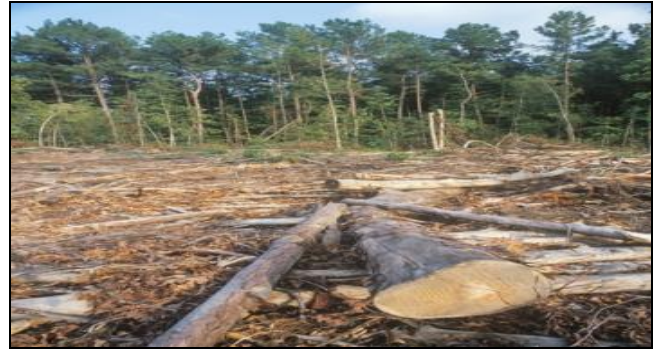

Figure 2. Forest depletion in Nigeria environment Source: Adopted from, Naij.com, media Ltd.2019

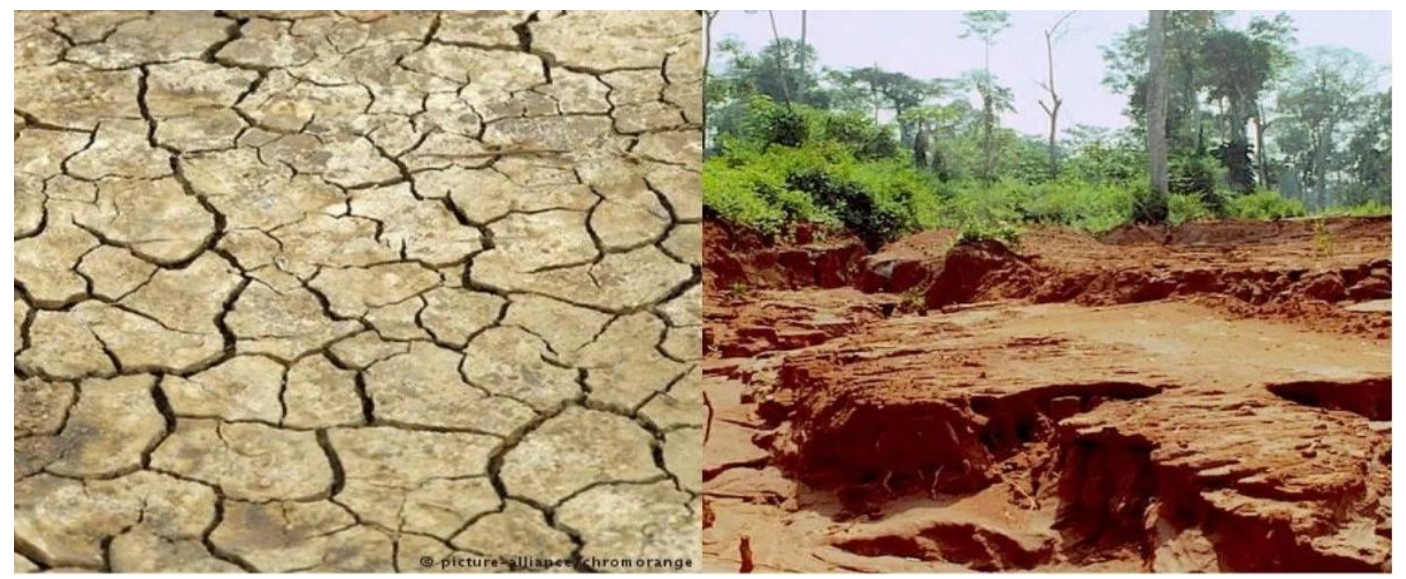

Figure 3. Deforestation leading to erosion impacts in Nigeria ${ }^{7}$

\section{Economic losses}

The tropical forests destroyed each year amounts to a loss in forest capital valued at US \$ 45 billion (Hansen, 1997). By destroying the forests, all potential future revenues and future employment that could be derived from their sustainable management for timber and non-timber products vanish.

\footnotetext{
${ }^{7}$ http://en.wikipedia.org/wiki/deforestation.
} 


\section{Social consequences}

The social consequences of deforestation are many, often with overwhelming long-term impacts. In Nigeria and among the local communities, the arrival of the so-called modernization usually means the destruction/change of their traditional life-style and the breakdown of their social institutions mostly with their displacement from their ancestral home. The intrusion of outsiders destroys traditional life styles, customs and religious beliefs which intensifies with infrastructure development like construction of roads which results into frontier expansion often with social and land conflicts (Schmink and Wood, 1992). The most immediate social impact of deforestation occurs at the local level with the loss of ecological services provided by the forests. By destroying the forests, we risk life of quality livability, risk the stability of climate and local weather, threaten the existence of other species and undermine the valuable services provided by biological diversity (Schmink and Wood, 1992).

\section{RESILIENCE STRATEGIES TO REDUCE DEFORESTATION IN NIGERIA}

The ways to reducing deforestation in Nigeria must go hand in hand with improving the welfare of stakeholders such as; the government of all cadres, cultivators, pressure group at the forest frontier among others. Any policy that does not carry other along is blemished and undesirable. There are no general solutions and strategies to challenges of deforestation as they vary from one region to the others or environment, as policies of government are not static as they may change over time.

The following are suggested efforts to control deforestation in Nigeria, they include:

\section{- Creation of Forest Reserves for Research Education}

These are areas delineated and gazetted by government for use as; making of useful logs for electricity and props, selling of forest produce and biodiversity through the creation of strict nature reserves and for research awareness in wetland conservation environment. All these have both social and economic advantages for the government, the community and the general masses.

\section{- Legislation}

In Nigeria from past to present, many laws and edicts have been enacted to control and enhance forest conservation. But the associate problem is that, these laws have not been properly utilized, as there are still found some forest defaulters who use forests for other nefarious activities like; kidnapping dens, cattle rustlings, and hidden places for highway robbers. Thus, there should be proper enforcement of policies measures to curb the menace.

\section{- Rainforest Management}

Many techniques have been utilized to manage the rainforest. These methods include; enrichment planting, tropical shelter wood system, taungya system, plantation establishment, and malayan uniform system etc. it is unfortunate that these management techniques have not been able to save the rainforest in Nigeria. Thus, new forest conservation methods must be encouraged through community participation and enlightenment programmes (Ogundele and Oladipo, 2016).

\section{- Encouragement should be given to private developers of forests}

Incentives like; free seedling distribution and free land holding should be provided for forest developers and cultivators. This will not only encourage more people into the trade, but sustains and increases Forest Area Plantation (FAP) and Area Permanent Reserve (APR) for timber production. A sustainable policy framework is important to give room for a progressive growth in the forestry industry throughout the country.

\section{- Lessening emissions from deforestation and forest degradation}

Many international organizations including the United Nations and the World Bank have begun to develop programmes to curb deforestation mainly through Reducing Emissions from Deforestation and Forest Degradation (REDD) which use direct monetary or other incentives to encourage developing country like Nigeria to limit and/or roll back deforestation. Significant work is underway on tools for use in monitoring developing country adherence to their agreed REDDS targets (Chomitz et al., 2007). 


\section{- Increase the area and standard of management of protected areas}

The provision of protected areas is fundamental in any attempt to conserve biodiversity (Myers, 1994; Myers and Mittermeier, 2000). Protected areas alone are not sufficient to conserve biodiversity; rather, they should be considered beside a wider stretch of areas and at a strategy place to conserve biodiversity. The minimum area of forest to be protected is considered to be 10 per cent of total forest area (Anonymous, 2010).

\section{- Encouraging substitutes For Timber}

Where tropical or other timber is used, other woods or materials could be substituted. We can stop using timber and encourage others to follow suit. Labeling schemes, aimed at helping consumers to choose environmentally friendly timbers are currently being discussed in many countries, Thus, Nigeria should be urged to do the same (Anonymous, 1990).

\section{- Increase area of forest plantation}

Increasing the area of forest plantations by using vacant lands, waste lands and marginal lands especially along road sides, railway tracts, on contours lines, avenues, and boundaries as well as on land not suited for agricultural production should have net positive benefits. Planting trees outside forest areas will reduce pressure on forests for timber, fodder and fuel-wood demands for use. In general, where trees fell, afforestation should take place in the areas as replacement (Anonymous, 2010).

\section{CONCLUSIONS AND RECOMMENDATIONS}

Finally, one can categorically conclude by saying that, most forest destructions in Nigeria is carried out by poor people, who are denied access to land and these people depend on the forest for their existence. Other infraction and causes include settlement expansion, large scale agricultural and development projects. The Nigerian rainforest has been seriously encroached upon and afforestation programmes in the country is inadequate. Also, most Nigerians are not aware of the consequences of deforestation; accordingly, awareness should be created. The achievement of the MDGs in the rural areas depend largely on the potentials of the flora and fauna species, some of which have not yet been discovered and documented by researchers. Women and their households' dependence on NTFPs, medicinal preparations, indigenous knowledge, building materials, good soils for agriculture, fresh water, industrial raw materials, erosion control, and exotic crops for domestication and so on, which in turn depends on the preservation of the forests. ${ }^{8}$

In view of the importance of forests and the consequences of deforestation, the under listed recommendations, which undeniably will help in the realization of the MDGs are made:

- agricultural science subject in secondary schools should be expanded to include relevant aspects of forestry, indigenous knowledge, rural development, agro-forestry and environmental sciences;

- budgetary allocations to all the three tiers of government should be increased and released promptly for forestry operations;

- the private sector and NGO's should be encouraged to participate in biodiversity conservation through grants and tax rebates;

- forest reserves should be established in mangrove ecosystem for in-situ conservation;

- researches should be embarked upon by foresters with the view to developing fast growing tree species as well as those resistant to fires and pathogenic attacks;

- through granting of grants, researchers can study both plants, forests and animals in-situ and benefits of this are reflected in institutions of higher learning and among specialists in the field of agriculture and biodiversity;

- rich and developed countries should fund afforestation programmes in Nigeria. Nigeria should stop gas flaring, rather the gas should be bottled and the cost subsided for rural people in order to reduce the pressure on fuel wood;

- environmental laws should be fully enforced and implemented in order to serve as deterrent to defaulters;

\footnotetext{
${ }^{8}$ http://en.wikipedia.org/wiki/Millennium
} 
- efforts should be made to domesticate some wild animals in order to reduce bush burning and hunting sprees;

- intensive agriculture whereby droppings of animals are used to increase fertility of the soil, thereby, utilizing a particular area for a long period should be encouraged. This will reduce the practice of shifting cultivation. Also, agro forestry and mixed cropping leading to the multiple use of the land should be encouraged;

- bush burning should be discouraged and where it is unavoidable, fire tracing should be embarked upon to prevent the fire from spreading beyond the anticipated area. Appropriate sanctions should be applied to defaulters;

- efforts should be made by the necessary institutions to encourage participatory forest management strategies merging the ideas and priorities of government, non-governmental organizations, foreign donors, forest communities, forest clubs and other stakeholders.

\section{REFERENCES}

Adebayo, A. A. (2010). Climate: Resource and resistance to agriculture. Lectures and Award of Prizes Committee (LAPC), Federal University of Technology.

Aderounmu, A., Akarue, J., Ette, M. (1992). A Forest Was Here. Newswatch Magazine, 16(24), Lagos, Newswatch Communications Ltd.

Aikhiombare, I. (2015). Deforestation in Nigeria: 7 Causes, 5 Effects and 6 Ways to Stop It. InfoGuide in Nigeria. InfoGuideNigeria.com

Akachuku, A. E. (2006). Disappearing Forests, the Consequences and Challenges of Sustainable Development in Nigeria. Pro. of Forest Ass. of Nigeria, 48-61.

Akintoye, O. A. (2003). Impact of Logging on Non-Logged Species and Effect on Rural Socio-Economic Development in Ikom Local Government Area. A masters of Science Degree Thesis, Department of Geography and Environmental Science, University of Calabar, Calabar, Nigeria.

Akintoye, O. A., Bisong, F. E., Utang, P. B., \& Andrew-Essien, E. (2013). Impact of Logging on Non-Logged Species in the Moist Forest Region of South Eastern Nigeria. Journal of Environment and Earth Science, 3(3), 62-70.

Akintoye, O. A., Eyong, A. K., Agada, P. O., Digha, O. N., \& Okibe, O. J. (2016). Socio-Economic Implication of Nigeria Liquefied Natural Gas (NLNG) Project in Bonny Local Government Area, Rivers State, Nigeria. Journal of Geoscience and Environment Protection, 4(05), 63.

Akintoye, O., \& Utang, P. (2012). Spatial disparity in employee composition in the oil industry in Nigeria and the implication of the Federal Character Policy. International Journal of Humanities and Social Science, 2(6), 133-140.

Andronache, I., Marin, M., Fischer, R., Ahammer, H., Radulovic, M., Ciobotaru, A. M., Jelinek, H. F., Di Ieva, A., Pintilii, R.-D., Drăghici, C.-C., Herman, G. V., Nicula, A.-S., Simion, A.-G., Loghin, I.-V., Diaconu D.-C. \& Peptenatu D. (2019). Dynamics of Forest Fragmentation and Connectivity Using Particle and Fractal Analysis. Scientific Reports, 9(1), 1-9.

Anonymous (1990). The Forest Resources of the Temperate Zones, Vol. II. FAO, Rome.

Anonymous, (2010). Global Forest Resources Assessment, 2010-Main Report. FAO Forestry Paper 163. Rome, Italy, 340 p.

Anonymous. (1994). Deforestation Technical Support Package. Third International Conference on Environment Enforcement, Oaxaca Mexico April 25-28, 1994. World Wildlife Fund; U. S. Environmental Protection Agency and U. S. Agency for International Development.

Bala, G., Caldeira, K., Wickett, M., Phillips, T. J., Lobell, D. B., Delire, C., \& Mirin, A. (2007). Combined climate and carboncycle effects of large-scale deforestation. Proceedings of the National Academy of Sciences, 104(16), 6550-6555.

Betts, R. A. (2000). Offset of the potential carbon sink from boreal forestation by decreases in surface albedo. Nature, 408(6809), 187-190.

Bounoua, L., DeFries, R., Collatz, G. J., Sellers, P., \& Khan, H. (2002). Effects of land cover conversion on surface climate. Climatic Change, 52(1-2), 29-64.

Carty, W. P. (1992). The Drying Forest. Newswatch Magazine, 16 (24), Lagos, Newswatch Communication Ltd.

Chakravarty, S, Ghosh, S.K., Suresh, C.P., Dey, A.N., \& Shukla. G. (2014). Deforestation: Causes, Effects and Control Strategies Global Perspectives on Sustainable Forest Management. In A. Okia (Ed) Global Perspectives on Sustainable Forest Management. Available online: http//www.Intechopen.com/books/global-perspectives-onsustainable-forest-management/deforestation-causes-and-control strategies

Chakravarty, S., Ghosh, S. K., Suresh, C. P., Dey, A. N., \& Shukla, G. (2012). Deforestation: causes, effects and control strategies. In Global perspectives on sustainable forest management. IntechOpen.

Chakravarty, S., Ghosh, S. K., Suresh, C. P., Dey, A. N., \& Shukla, G. (2012). Deforestation: causes, effects and control strategies. Global perspectives on sustainable forest management. IntechOpen, Available from: http://www.intechopen.com/books/globalperspectives.

Chomitz, K. M., Buys, P., Luca, G. D., Thomas, T. S., \& Wertz-Kanounnikoff, S. (2007). At loggerheads? Agricultural 
expansion, poverty reduction and environment in the tropical forests. World Bank Policy Research Report. World Bank, Washington DC.

Economic Forestry Commission (EFC) (2010). Background Paper for the Forest and Water Segment, European Forestry Commission, $35^{\text {th }}$ session, 27-3 April 2010, Lisbon, Portugal.

FAO (2001). State of the World's Forests. Food and Agriculture Organization, Rome.

Foley, J. A., DeFries, R., Asner, G. P., Barford, C., Bonan, G., Carpenter, S. R., ... \& Helkowski, J. H. (2005). Global consequences of land use. Science, 309(5734), 570-574.

FORMECU (1996). Statistics of Forest Reserves in Nigeria. Forestry Management, Evaluation and Coordinating Unit, Nigeria.

Friedlingstein, P., Cox, P., Betts, R., Bopp, L., von Bloh, W., Brovkin, V., ... \& Bala, G. (2006). Climate-carbon cycle feedback analysis: results from the C4MIP model intercomparison. Journal of climate, 19(14), 3337-3353.

Habitat. (2017). Habitat Country Programmes and Documents in Asia. Un-Habitat Global Activities Report 2017.

Hansen, C. P. (1997). Making Available Information on the Conservation and Utilization of Forest Genetic Resources. The FAO Worldwide Information System on Forest Genetic Resources.

Kleidon, A. (2000). Green planet versus a desert world: Estimating the maximum effect of vegetation on the land surface climate. Climatic Change. 44 (4), 471-493.

Lanly, P.J. (1983). Assessment of the Forest Resources of the Tropics: A Review of Articles in Forestry Abstract 4 (6), $287-318$.

Larcher W. (2001). Physiological Plant Ecology: Ecophysiology and Stress Physiology of Functional Groups. Sinauer Associates.

Magrin G, Garcia CG, Choque DC, Giménez CJ, Moreno AR, et al. Climate Change (2007): Impacts, Adaptation and Vulnerability. Contribution of Working Group II to the Fourth Assessment Report of the Intergovernmental Panel on Climate Change. Cambridge University Press, Cambridge, UK.

Mather, A. S. (1991). Global Forest Resources. International Book Distributors, DehraDun.

McCarthy, J.J., Canziani, O.F., Leary, N.A., Dokken, D.J., White, K.S. (2007). Climate Change Impacts, Adaptation and Vulnerability, Contribution of Working Group II to the Third Assessment Report of the Intergovernmental Panel on Climate Change. Cambridge University Press, Cambridge, UK.

Mfon, P. (2003). Impact of Logging on the Forest Diversity of Iwuru, South Eastern Nigeria. A Master of Science In Environmental Protection and Resources Management Degree Thesis, Department of Geography and Regional Planning, University of Calabar, Calabar, Nigeria.

Mfon, P., Akintoye, O. A., Mfon, G., Olorundami, T., Ukata, S. U., \& Akintoye, T. A. (2014). Challenges of Deforestation in Nigeria and the Millennium Development Goals. International Journal of Environment and Bioenergy, 9(2), 76-94.

Myers, N. (1994). Tropical deforestation: Rates and Patterns. The Causes of Tropical of Tropical Deforestation. The economic and statistical analysis of factors giving rise to the loss of the tropical forest, eds. Brown, K. and Pearce, D. pp 27-40. UCL Press.

Myers, N., Mittermeier, R. A., Mittermeier, C. G., Da Fonseca, G. A., \& Kent, J. (2000). Biodiversity hotspots for conservation priorities. Nature, 403(6772), 853-858.

Naij.com (2019). Deforestation in Nigeria and its implication on economy - Legit.com media Ltd.

NEST - Nigerian Environmental Study Group (1992). Nigeria’s Threatened Environment: A National Profile, Ibadan, Nigeria, Intel Printers Limited.

Nwoboshi, L.C. (1982). Tropical Siluiculture Principles and Technique, Ibadan Nigeria, Ibadan University Press.

Ochanda, N., \& Epp, H. (1982). Monitoring recent changes in extent of natural forests in Kenya using remote sensing techniques. In International Society for Photogrammetry and Remote Sensing, International Symposium, Toulouse, France, 489-496.

Ogundele, A. T., \& Adebisi, O. M. (2016). Deforestation in Nigeria: The Needs for Urgent Mitigating Measures. International Journal of Geography and Environmental Management, 2(1), 15-26.

Okojie, J. A., \& Okali, D. U. U. (Eds.). (1993). Lost Crops of Nigeria: Implications for Food Security: Proceedings of the Seminar Held at the University of Agriculture, Abeokuta, Nigeria, 21 $1^{\text {st }}-22^{\text {nd }}$ May 1992. University of Agriculture, Abeokuta.

Park C. C. (1992). Tropical Rain Forests. London, Routledge. Inducgtion.

Pintilii, R. D., Andronache, I., Diaconu, D., Dobrea, R., Zeleňáková, M., Fensholt, R., ... \& Ciobotaru, A. M. (2017). Using fractal analysis in modeling the dynamics of forest areas and economic impact assessment: Maramureș County, Romania, as a case study. Forests, 8(1), 25.

Rainforest Mongaby (2007). Nigeria. Environmental Profile: Deforestation Rate and Related Forestry Figures, (http://rainforest.mongaby.com/deforestation/2000/Nigeria.htm).

Sands, R. (2005). Forestry in a Global Context. CABI Publishing.

Schmink, M., \& Wood, C. H. (1992). Contested frontiers in Amazonia. Columbia University Press.

UNEP (2004). Protected Trees, Plant and Animal Biodiversity - United Nations Environment Programme-World Conservation Monitoring Center (UNEP-WCMC). World Database on Protected Areas.

Walker IJ, Sydneysmith R. (2007) British Columbia; in From Impacts to Adaptation: Canada in a Changing Climate. Canada, Ottawa, 329-386.

http://en.wikipedia.org/wiki/deforestation

http://en.wikipedia.org./wiki/deforestation

http://en.wikipedia.org/wiki/Millennium

Submitted:

April 14, 2019
Revised:

July 20, 2019
Accepted and published online August 28, 2019 